\title{
A Method to Increase the Viability of Cyprinus carpio (Linnaeus, 1758) Stocking of the Aquatories Under the Influence Advanced Biotechnologies
}

\author{
Olena Honcharova ${ }^{1, \#, *(\mathbb{D}, \text { Pavlo Kutishchev }}{ }^{1, \#}$, Yevgen Korzhov ${ }^{1, \#}$
}

${ }^{1}$ Kherson State Agrarian And Economic University, Dept. of Water Bioresources and Aquaculture, Kherson, Ukraine.
\#These authors share the first authorship.

\section{How to cite}

Honcharova, O., Kutishchev, P., Korzhov, Y. (2021). A Method to Increase the Viability of Cyprinus carpio (Linnaeus, 1758) Stocking of the Aquatories Under the Influence Advanced Biotechnologies. Aquaculture Studies, 21, 139-148. http://doi.org/10.4194/2618-6381-v21_4_01

\section{Article History}

Received 03 November 2020

Accepted 26 March 2021

First Online 29 March 2021

Corresponding Author

Tel.: +380557735488

E-mail: anelsatori@gmail.com

\section{Keywords}

Carp

Food factor

Natural feed

Growth

Physiological processes

\begin{abstract}
This research investigated Spirulina Platensis, Chlorella vulgaris and Artemia salina as additional sources of protein and biologically active substances that affect the parameters of the carp body. Additional addition of carp to the diet in the ratio: Spirulina Platensis - 40\%, Chlorella vulgaris - 30\% and Artemia salina - $30 \%$ made an impact on the parameters of carp development. The components were cultured in a bioreactor built into a recirculating aquaculture system. The results showed that after additional feeding of carp with the indicated components, the body weight of one-year carp was higher than the control group by $8.9 \%$, and safety by $3.4 \%$. Body weight twoyear carp was greater in the experimental group than in the group where the fish ate the total diet. The difference was $12.1 \%$ in body weight and $2.9 \%$ in safety. These parameters were significantly lower in fish fed the control diet $(P<0.05)$. This scientific work has demonstrated the additional use of natural food as a method for improving the blood composition of carp: an increase in hemoglobin by $15.5 \% \quad(P<0.05)$, erythrocytes by $5.5 \%$ in comparison with the control group. Indicators of gas-discharge visualization of a biological object supplemented the obtained result.
\end{abstract}

\section{Introduction}

The results of monitoring observations of current state and development trends of Ukrainian fish industry, first of all, show a high level of water pollution, irrational use of the potential of aquatic bioresources, and as a result, a tendency of reduction of fish resources (Korzhov, Kutishev \& Honcharova, 2020; Sherman et al., 2013). Any water area constitutes an ecosystem with a certain bioproductive potential, which is formed by the interaction of the entire complex of factors of different origins. An important aspect is correlation of each of these elements, as far as they have direct or indirect influence on the dynamics of quantitative and qualitative or species composition of hydrobionts in different trophic levels, determining the feed capacity of water reservoir and the balance of ichthyofauna (Korzhov \& Honcharova, 2020). Consequently, there is a question that requires urgent solution: a stocking of reservoirs of different forms and targets with stock, the organism of which is functionally active and has a high level of viability. Through the example of small storage reservoirs, transformed aquatories, these issues can be resolved and improve their condition by the artificial reproduction of valuable industrial fish species with preliminary growth of fish stock material for annual introduction and preservation of ichthyofauna. In resolving of stated issues, technological aspects of 
growing and ongrowing of hydrobionts, particularly, fish stock material of carps, are classic with harmonizing of existing national norms and standards. Using them as basic aspects, it is possible to develop and optimize this process in conditions of natural succession and anthropogenic influence. One of the currently important ways to increase the growth rate of hydrobionts, which is widely practiced, is the use of metabolites, growth stimulants of chemical and hormonal type. However, such an application is reflected in the future in qualitative characteristics of fish-breeding product. At the end of growing in this way of stocking, and after the stocking, it can lead to aggravation of ecological condition of the water reservoirs, and in the same way, to misbalancing the ecosystem in general. Physically caused the occurrence of the corrective effect of the influence of any substance, which enters the organism of fish by neurohumoral regulation of metabolic reactions (Hrytsyniak, Chuklin \& Buzevych, 2013). The development of technology for on growing of young fish in the recirculation systems with extra feeding with natural components against the background of introduction of energy-saving elements to the technological plan acquires a practical value.

In numerous scientific and practical works, the authors note that in the first days of life of fish it is necessary to provide a proper feeding of the young stock in order to intensively form its internal organs, immunity for the quick growth. There are many ways to improve fish productivity, using the optimization of the general diet. The use of non-traditional feed additives in fish breeding (Merzlova, 2014; Sherman, 2002; Deren et al.,2011). However, the production of components does not involve their previous cultivation and inclusion in the technological scheme, contrary to the method presented in this article. Positive results are presented by the authors in studies of the influence of fly larvae flour in feeding of young fish, effect of replacement of fish meal with broiler chicken viscera on growth, feed utilization and production, which are a source of proteinand stimulates the processes of digestion of nutrient chemicals of feed in the gastro-intestinal tract of fish (Kolty 'pin, 1975; Alofa, Oke \& Abou, 2016). It should be noted that in the available literature, it is possible to separate the only information on the presence of a positive influence of the use of nontraditional for fish industry types of feed and biologically active additives. The effect can be more or less expressed which depends on the goal and the action vector of each of the elements. Upon the review of international literature sources, there is information with recommendations to pay attention not only to the effect of action, but also to the after-effect of the use of certain element of extra feeding. For example, there is a positive experience of using not only green mass amaranth silage, but also oil and seed flour. It is found that the feeding of ground grains and amaranth oil in the main ration of two-year-old carp helps to improve the physiological state of the organism of fish, increase the growth rate and reduce the costs of feed for breeding (Palamarachuk \& Deren, 2018). In aquaculture, there are the attempts to use non-traditional sources of protein as food for hydrobionts: the quality fish-flour (Alofa, Oke \& Abou, 2016; Zheltov, 2008). Key issues come to the forefront: today, the organic products with insect substrate and biomass still produced on a relatively small scale, which causes a high cost, comparing to the most other protein sources. The relevance of the use of natural feed as protein source is due to the fact that a number of practical studies have shown the resistance of microorganisms to the antibiotics in humane medicine, as a consequence of the use of antibiotics as the stimulants of growth in animal breeding, including fish breeding (Adams, 1999; Honcharova et al., 2019; Wan, 2019). To examine the effectiveness of multi-purpose module recirculation system for on growing of hydrobionts, cultivating natural feeds and obtaining additional products of aquaculture. To study the influence of the feed factor on the functional state of organism of carp in ontogenesis against the background of the introduction of elements of advanced biotechnologies. To substantiate experimentally the positive influence of the proposed method of on growing of fish in order to increase fish productivity of the aquatories as a result of stocking them with viable, resistant to the environmental factors of ecosystem young fish against the background of using advanced energy saving technologies in the technological cycle.

\section{Materials and Methods}

The part of the analyses was processed in the laboratory of the "Kherson Production and Experimental Plant for Breeding of the Ordinary Fish" State Institution and "Aquaculture Perspectives" Scientific Research Laboratory, "Scientific Research Laboratory of Physiological and Biochemical Research named in honor of S. Pentelyuk", Scientific Research Laboratory on ecological and chemical analysis and water monitoring of Public higher education institution Kherson State Agrarian and Economic University (KSAEU).

\section{Object of Research, Growing Conditions}

Carp (Cyprinus carpio L.) first body weight $0.315 \pm 0.06 \mathrm{mg}$. Fish were reared in tanks (volume $=250 \mathrm{dm}^{3}$, as the fish grow $=500 \mathrm{dm}^{3}$ ) in an indoors recirculation system. The set task is being achieved by the fact that the young fish, in order to increase their viability and growth intensity, is being placed in the recirculation system of the basin type with the division into control and exposure groups of the experiment. At the beginning of the experiment, there were 200 fish specimens in each basin. As the carp grew, the stocking rate of 20-30 g was taken into account - up to 150 fish per cubic meter. Actually, the process of carp on growing takes place from the section of young fish 
growing to the section of natural feed cultivation in a single system, its processing against the background of introduction of the alternative energy sources, gasdischarge visualization method using hardware and software complex of the GDV-bioelectrography. Besides that, the installed module system provided the use of special net pens, where the growing of bivalve mollusks and crustaceans was being practiced. They were immersed to the bottom of the tanks, in the case of natural mortality of young fish; the remnants of feed and organic matter were consumed by crustaceans, reducing the pressure of organic matter on the filtration system. Carp (Cyprinus carpio L.) were hand-fed thrice a day (08:00 h, 12:00 $\mathrm{h}$ and 18:00 h) to apparent satiation and the amount of feed consumed recorded for each tank of the recirculation system. A schematic representation of a modular system, a bioreactor where biomass is cultivated, fish basin is shown in Figure 1.

\section{Ingredients of the Diets and Cultivation Conditions}

Additional addition of carp to the diet in the ratio ingredients: Spirulina Platensis - 40\%, Chlorella vulgaris - 30\% and Artemia salina - 30\%. All components for future feeding of carp were cultivated in the laboratory. In the module installation, the sectional units of reservoir for the cultivation Spirulina Platensis, Chlorella vulgaris and Artemia salina are provided in previous articles (Honcharova et al., 2020; Pivovarov, Mykolenko \& Honcharova). The supplying is carried out from the main fish tank and the rest of the water comes from an autonomous pump from the storage tank and bioreactor. The prepared water in the bioreactor was manually brought in once a week into the tanks 1:2 (for the Spirulina Platensis, Chlorella vulgaris) and 1:3 (for the Artemia salina). The food mass for feeding was formed in the laboratory of the aquatic bioresourses and aquaculture of KSAU on its own extrusion device, configured for relatively small volumes and in the laboratory of the "Kherson Production and Experimental Plant for Breeding of the Ordinary Fish" State Institution, where the main experimental part of the work was implemented and the installation with basins and bioreactor was modeled. After the cultivation, natural feed was filtered, processed and weighted for further introduction into the total feed mass. The water from the fish-breeding systems, which is enriched with nutrients, was partially used as the nutrient medium. When using water from fish-breeding ponds as a nutrient medium, the microalgal culture allowed providing the biological purification of water and to obtain a biomass, enriched with essential nutrients. Natural food from ingredients was added by hand every day.

The Spirulina Platensis that was used to feed the carp was green and slightly salty. In percentage (\%): moisture - 10; dry matter - 90; crude protein - 62; carbohydrates - 14.7; fats - 4; fiber - 3; ash - 6.3. Composition Percentage of Artemia salina, which was used to feed the carp was as follows (\%): moisture - 12; dry matter - 88; crude protein - 53; carbohydrates - 12; fats -3.2; fiber - 6; ash - 4. Composition Percentage of Chlorella vulgaris which was used to feed the carp was as follows (\%): moisture - 11; dry matter - 89; crude protein - 59; carbohydrates - 13 ; fats -3.2 ; fiber - 4 ; ash 6.

The technological aspects of preparing a feed additive for the experimental group are shown in Figure 2.

At the beginning of the first stage of development, carp fish were being fed with finely dispersed flour (0.1$0.2 \mathrm{~mm}$ ) at the ratio $1: 1$ according to the requirements

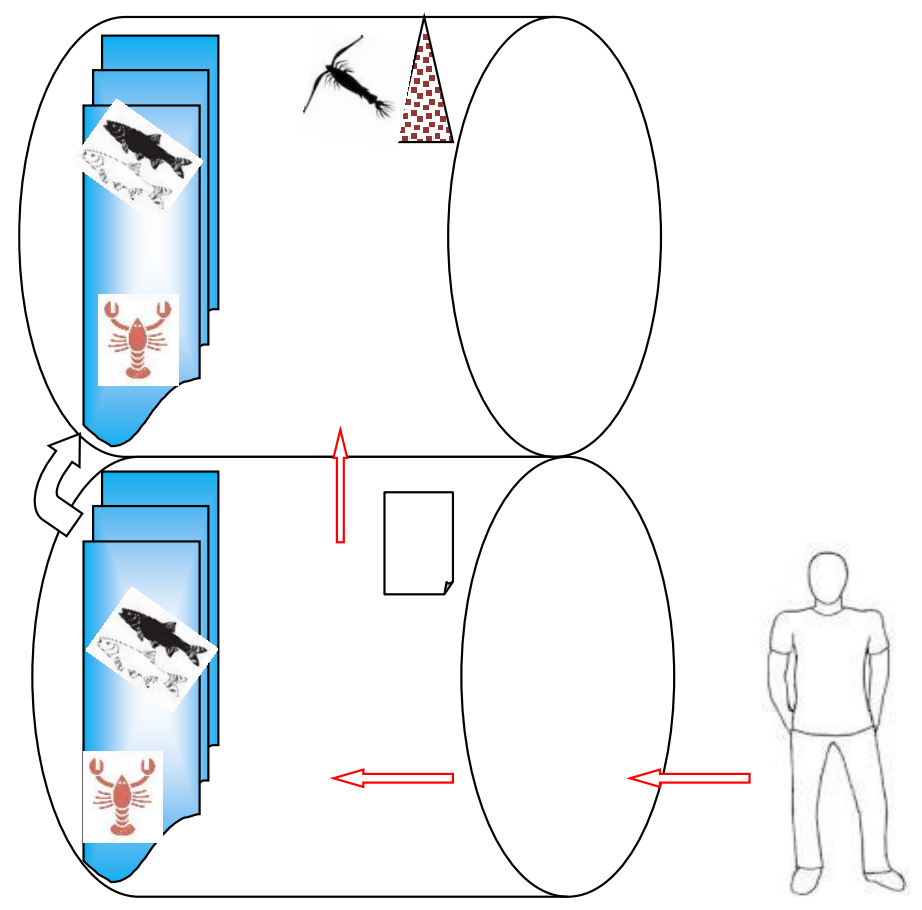

Figure 1. Modular system that was made for the experimental part 


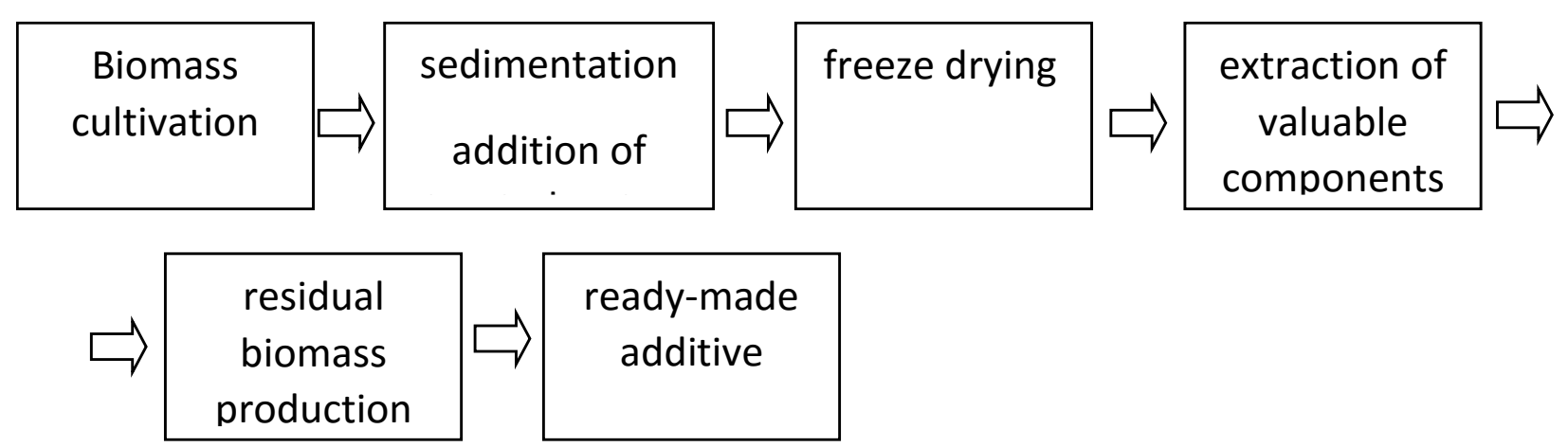

Figure 2. Technological aspects of the preparation of feed ingredients for addition during feeding to the experimental group

of standard ration in fish breeding. Ingredient content, $\%$ : fish meal (13), meat and bone meal (5), grass meal (3), wheat (9.5), sunflower meal (40), peas (10\%), feed yeast (18.5), premix (1). The experimental group of fish received the same as the control general diet. When feeding the fish of the experimental group, processed nauplii of Artemia salina, Chlorella vulgaris and Spirulina Platensis cultures were introduced. With each week of development, during the feeding, the amount of feed was increased in proportion to the body weight against the background of monitoring of the general functional status of the carp organism by the biopotential of structure and functional connections of the changes in the energy of fixation on the GDV-Camera device (Vainshelboim et al.,2005; Korotkov, Matravers, \& Orlov, 2010; Kobets et al.,2016). The bioreactor for the cultivation of Artemia salina, Chlorella vulgaris and Spirulina Platensis consisted of an aeration mechanism, a set temperature with a timer, and a storage reservoir with a medium, which also according to the timer worked systematically. Previously prepared water was being supplied to the bioreactor. The fish tanks had an autonomous interconnection with bioreactor, the discharge of the nutrient medium was being held systematically. During the feeding, the pump mechanism and the filtration system were turned off. A solar panel was installed as an additional source of energy, which brought a possibility to use the alternative sources of energy for the additional aeration and lighting for aquaponics in the system of fish tanks. The development of microalgae was monitored visually using light microscopy; the level of microalgae pigmentation was defined in particular.

\section{Studying the Development of Carp}

The development rate of the young carp was studied based on the results of the control weighing by selecting 40 specimens from each basin, and for morphological, physiological and biochemical studies 12 specimens were selected. The survival rate was determined during the experimental part by final number of fish/initial number of fish based on the percentages (\%). The carp weight was determined by weighing the fish during the experiment (g). Analysis of the development rate of the carp fry in ontogenesis against the background of the influence of feed factor: at first experiment June 1; in June 15; in June 30; in July 15; in July 30; in August 15; in August 30; in September 15; in September 30. Analysis of the development rate of young-of-the-year carp in ontogenesis against the background of the influence of feed factor: at first experiment; in 30 days; in 60 days; in 90 days; in 120 days; in 150 days; in 160 days.

\section{Biochemical and Morphological Studies}

The blood from heart and tail vein was obtained using Pasteur needle and heparinized syringe. For biochemical studies, apart from blood plasma, the muscle part was also collected. They were also frozen in ThermoMix and stored for further research. Cytological studies of the leukocyte formula were performed on blood smears stained by the method of RomanovskyGiemsa and using a digital camera and Micromed microscope. Muscle protein content was determined by the Lowry method, and plasma glucose content was determined by the glucose oxidase method using commercial standard sets. Biochemical studies of biological material were performed using ULAB 102 spectrophotometers.

\section{Hydrochemical Monitoring}

Hydrochemical monitoring in the module system was performed systematically by express methods and in the laboratory according to the leading commonly accepted indicators in fish breeding (Alyokyn, 1970). Parameters such as temperature $\left({ }^{\circ} \mathrm{C}\right), \mathrm{pH}$, dissolved oxygen (mg/L).

\section{Additional Exploration of Gas Discharge Imaging}

The studies of the biopotential of carp were carried out on a GDV-Camera, which is similar in principle to the method, used by the authors previously (Kobets et al.,2016), the study of the functional activity of biological objects implemented using gas-discharge visualization method ("Kirlian effect"). As a result of fixating the object of measurement, the software was 
processing the GDV-gram (the electric impulse at the intermolecular level came through a conductor structural protein complexes, tissues, and transformed on the surface into electropunctural nodes with further processing on computer equipment), taking into account the given vector of the coefficient of study format, the radius and length of the isolines, entropy and fractality. In order to determine the optimal concentrations of the work solution of the medium for the cultivation of the natural feed, a method of bioelectrography was used. As a result of fixation of biopotential of the aquatic environment and directly the young carp (Cyprinus carpio L.), by processing the digital values of the main parameters, on the appropriate equipment, the optimal indicators were determined. The electrical discharge of the luminescence on the surface of the objects in a variable electric field of high frequency was detected using the equipment of the GDV Scientific Laboratory. The resulting GDV-grams (photos processed by the GDV Scientific software) were interpreted in terms of the intensity and the colorless scale, and a statistical analysis was carried out for the data obtained.

\section{Statistical Analysis}

The comparison of the average values between different samples was performed by the Student's ttest. In interpreting the obtained results, the context of complexity and correlation of every studied parameter were taken into account.

\section{Results}

One of the leading and determining indicators that have a direct influence on the biological potential of fish is development rate. The influence of the feed factor on the functional state of the carp organism in ontogenesis is presented in the Figure 3, where the tendency of increasing of this factor in the fish of the experimental group in relation to the control group can be noted.

Thus, the variation in average body weight of young-of-the-year carp of the experimental group relatively to the control group was $8.9 \%$. The on growing of young-of-the-year carp during the growing season in the module system using the method of feeding natural processed food against the background of the general farming ration supported the activation of the metabolic processes, which positively affected the development rate of fish (Figure 4).

The difference in the body weight of fish at the end of the growing season between the control and experimental groups was $12.1 \%$. Probably, the feed factor supported the correction of the physiological and biochemical processes together with the activation of the last-named in the organism of carp of the experimental group. The next, no less important, indicator in fish breeding is the survival rate of the hydrobionts. When studying the effectiveness of the influence of growing and feeding conditions, it only complements the results and provides an opportunity to make more complex assessment. Thus, against the background of visual observation of ethology of carp in the ontogenesis of the control and experimental groups, where young-of-the-year carp fish were more active in feeding, movable in the environment of the experimental group, a higher percent survive of youngof-the-year from the fry was registered in the experimental group; the variation was $3,4 \%$ relatively to the control group. The percent survived of two-year from the one-year carp in the experimental group was $85.0 \%$, which exceeded the control values by $2.9 \%$ (Figure 5).

Let's focus on the importance of conducting complex research in studying of influence of the feed factor on the functional state of the carp organism, which provides an opportunity to assess the use of the module system in the context of the advanced

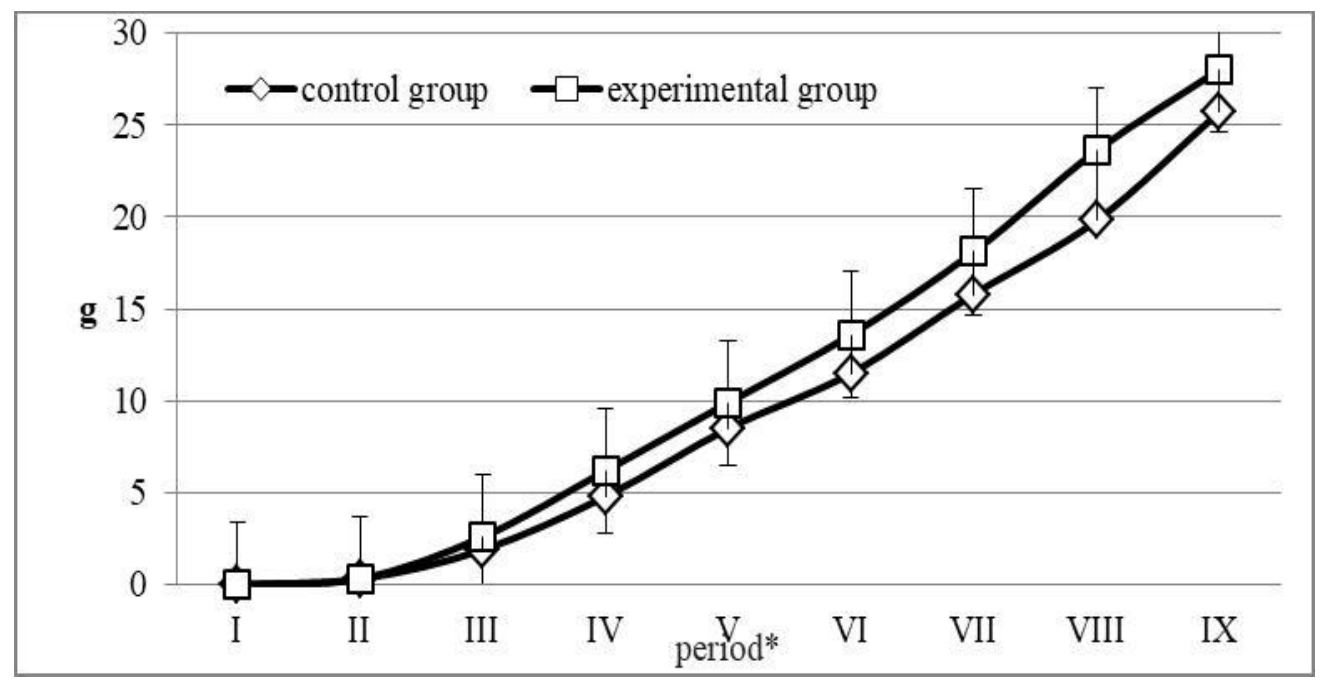

Figure 3. Analysis of the development rate of the carp fry in ontogenesis against the background of the influence of feed factor (*I-June 1; II-June 15; III-June 30; IV-July 15; V-July 30; VI-August 15; VII-August 30; VIII-September 15; IX-September 30), M \pm , $\mathrm{n}=40$ 


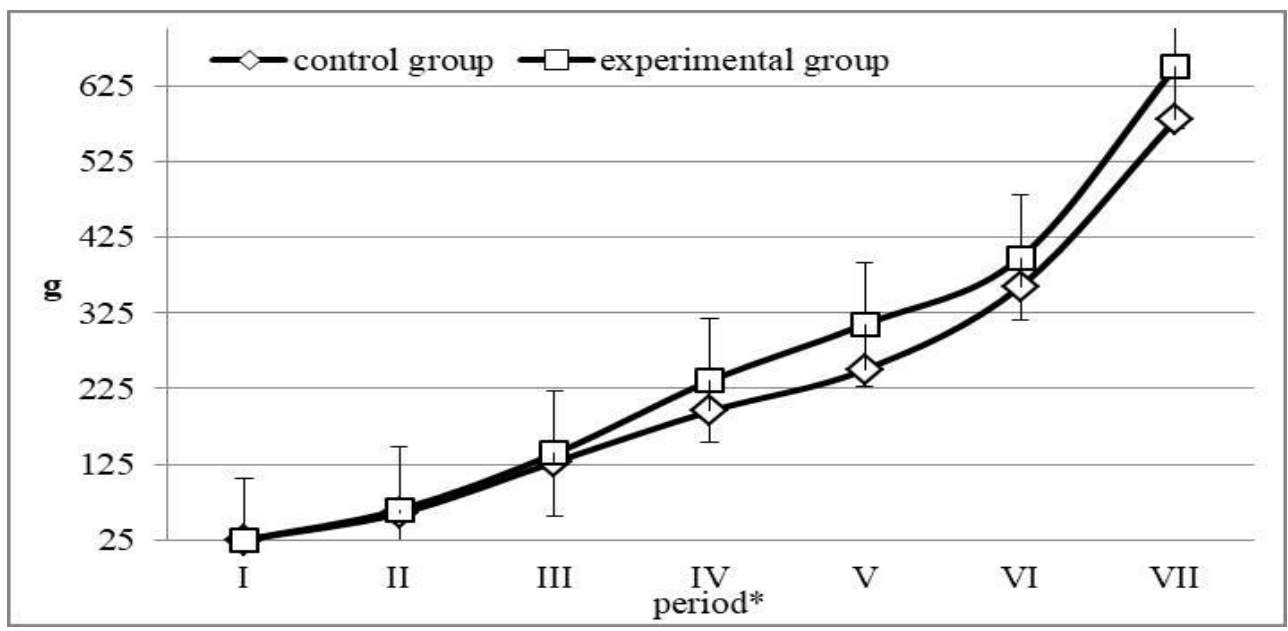

Figure 4. Analysis of the development rate of young-of-the-year carp in ontogenesis against the background of the influence of feed factor ( $*$ I-the beginning of the experiment; II-30 days; III-60 days; IV-90 days; V-120 days; VI-150 days; VII-160 days), M \pm m, $n=40$

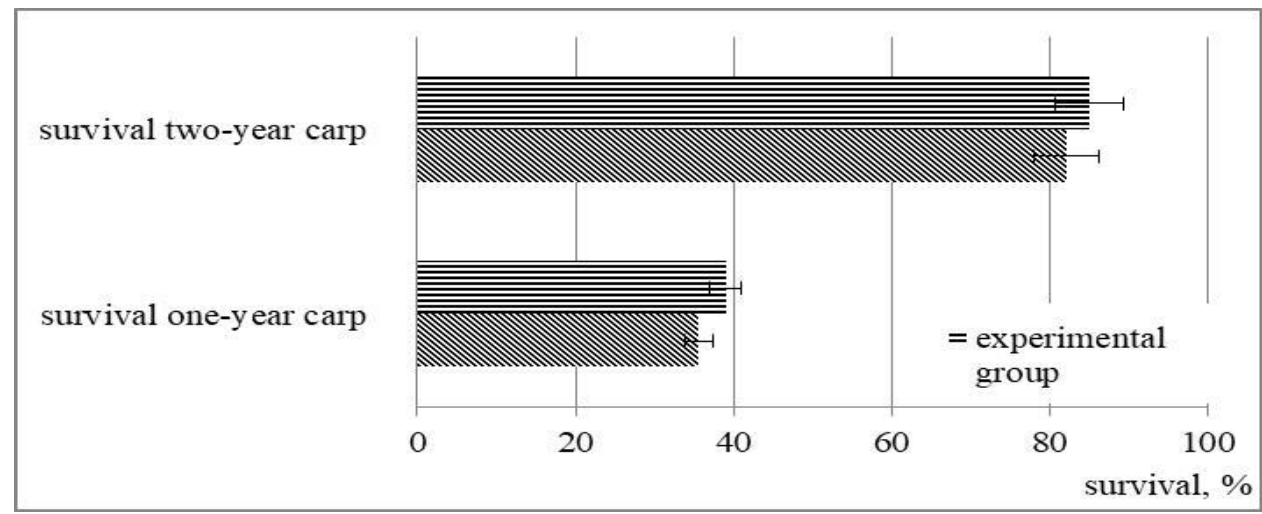

Figure 5. Analysis of carp survival in ontogenesis against the background of the feed factor, $\%, M \pm m$

biotechnologies more objectively. The analysis of the gas-discharge visualized GDV-gram images allowed completing the obtained positive results on the development rate of carp against the background of extra feeding is presented in the Figure 6.

Thus, the field, in which the fixation of the object the carp fish, was being held, under the influence of voltage, formed the "corona glow effect" of the electrons and photons; therefore, the intensity of each of the radiations depended on the general functional state of the biological object. The interpretation of the obtained results was based on the nature of such radiation, spatial distribution of the loci of different spectrum. The obtained GDV-grams were processed by a special program and a set of certain parameters was formed for each GDV-gram. As a result of analysis of the GDV-grams, the following informative indicators can be noted: the intensity of brightness (in the control group, it was $0.491 \pm 0,015$, in the experimental group, it was $1.452 \pm 0,012$ and the form coefficient $(1.21 \pm 0.23$ and $2.72 \pm 0.21$ respectively, $\mathrm{P}<0,05)$. The obtained difference of the studied indicators can be explained by the previously established growth rates of carp of the experimental group. Presumably, the decrease of the body weight was morphologically reflected in the own shape of the object in the context of the optoelectronic emission, the proportion of skeletal and muscular parts, the blood state etc.

The obtained GDV-gram results complement the positive effect of the on growing of the hydrobionts by the proposed method; this provides the opportunity to predict the operational assessment of the influence of a particular technological or any other factor on the functional state of the organism. Besides that, after analyzing the GDV-grams in the experimental and control groups, the informative parameters were noted, which had differences in the numerical processing of physical and optical GDV-grams of the biopotential of the measured objects.

According to the results, all the studied indicators of hydrochemical state of the reservoirs of the module system corresponded to the acceptable limits of fluctuation: the concentration of free hydrogen ions (pH)-7.21; oxygen concentration-5.2 mg/l; temperature-22-24 ${ }^{\circ} \mathrm{C}$, mineralization-365 mg/dm ; nitrites and nitrates- 0.09 and 1.1 respectively.

The study of morphological and physiological state of carp blood on the background of the influence of the feed factor reflected the adaptability and functionality of homeostasis of their organism. The study of 
hematopoiesis in carp organism under the influence of technological factors of cultivation is quite informative: firstly, it is possible to assess the respond reaction of the tissue system and organs of fish to changes in the complex of both internal and external factors. It is worth mentioning that the number of erythrocytes should be considered with the content of hemoglobin, as their functionality provides with the absorption of oxygen and its transport to the capillaries of tissues, followed by absorption of carbon dioxide and transfer to the gill apparatus. In the experimental group, these processes were more active, as evidenced by higher values of these structural elements by 5.5 and $15.5 \%$ respectively, the parameters in the control group. This course of processes indicates the increase in the intensity oxidation-reduction processes and a positive effect on the development of carp organism in the experimental group (Table. 1).

The obtained results of the study of morphological and functional parameters of blood under conditions of carp on growing in the module system showed a lower concentration of glucose in blood of carp of the control group, which was less than the values in the experimental group by $7.8 \%$. This may be due to the activation of metabolic processes and rapid split of simple nsugar compounds in the blood of the experimental carp. The level of protein metabolism reflects the content of total protein, most probably that the redistribution of fractions forms the main parameters and determines the immunobiological reactivity of the organism, reticuloendothelial system under the influence of various environmental factors and the technology of cultivation. Besides that, this parameter informs about the level of activity of the physiological processes in the liver, which were more active in the organism of carp of the experimental group, as well as the dynamics of the development rate, which reflected in the body weight of fish. The study of non-specific immunity, the possibilities of presence of inflammation focuses of complex values or allergic reaction in the organism of carp of the control and experimental groups showed that the parameters conform to the physiological and biochemical standards in fish breeding. Besides that, the redistribution of these formed elements in each of the groups was fixated within the acceptable limits. The blood of carp had a lymphoid kind, with typical groups of leucocytes at different stages of cytogenesis: granulocytes, agranulocytes, there were also the ballast forms of myeloblasts, hemocytoblasts. The variation of the values of formed elements provided an opportunity to discuss the protective capabilities of the carp organism. Physiological state of carp blood on the background of the influence of the feed factor are presented in the Table 2.

The study of the influence of technological factors on the physiological and biochemical processes in the organism of carp complements the analysis of the most reactive blood cells, sensory to the impact of factors of different nature of neutrophils. The correspondence of the values with physiological standards is confirmed by the obtained numeric results and provides an opportunity to note the stability of homeostatic balance, regeneration processes in organs and tissues, as well as phagocytic activity. Consequently, the study of the functional state of carp organism in ontogenesis under the influence of technological factors and carp from the control group showed positive substantiated results on feeding fish by the proposed method in the module system. It was interesting, in the context of objectivity and complexity, to study the chemical composition of the muscle part of carp in the experimental and control groups. Since, after the stocking, this viable young fish should be adapted to the influence of the technogenic factors, certain trophic links and have high biological potential against the background of the formation of qualitative characteristics. The best qualitative characteristics of muscular tissue were in the organism of carp which was on grown in the module system using extra feeding with natural processed food in the bioreactor. With the feed coefficient of 2.4 in the control group, in the experimental group it was 2.2 , the mobilization of all reserve systems in the organism of the experimental group and better absorption of feed nutrients against the background of the higher indicator of the development rate and percent survived can be noted. The analysis of carp muscular tissue, which was on grown in the experimental group, showed that meat has a higher percentage of protein and fat. While the concentration of ash did not differ significantly, which caused by the consumption in some ways the same amount of minerals with compound feed. At the visual assessment, the meat in the section was homogeneous and had distinctive color and smell in each of the groups of the experiment.

\section{Discussion}

In the scientific and practical works, considerable attention is paid to the issue of optimization of aspects of cultivation technology of stocking material for the purpose to increase the efficiency of fish breeding use of the reservoirs (Sherman et al., 2013; Hrynzhevskyi \& Pekarskyi, 2004). However, the technology of growing the stocking material, described in the special literature, is adapted for the relevant fish breeding areas, and the differences are presented only in the normative indicators of planting density of fry and young fish in the cultivation of young-of-the-year carp. Along with that, the further targeted use of planting stock material is often not taken into account, which makes it topical to improve the technology of growing the viable planting stock material in order to use it for stocking of the reservoirs. When extra feeding the hydrobionts, in the available literature, there is information that reflects the positive experience of using biologically active additives, growth stimulants, adaptogens of various nature that 


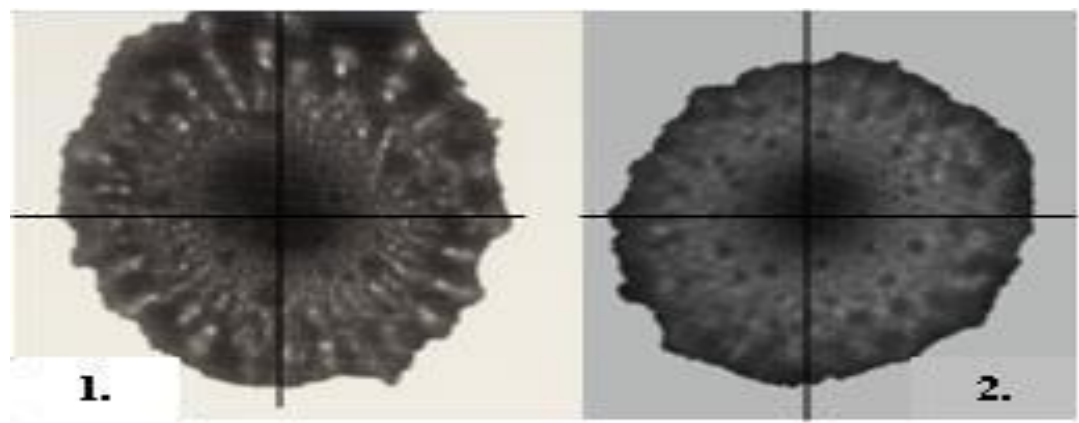

Figure 6. The comparative characteristics of the GDV-grams of carp under the conditions of the extra feeding with natural feed from the bioreactor of the module recirculation system: 1 - GDV-gram of carp of the experimental group; 2 - GDV-gram of carp of the control group

Table 1. Physiological state of carp blood on the background of the influence of the feed factor, $M \pm m, n=20$

\begin{tabular}{lcc}
\hline & \multicolumn{2}{c}{ Groups } \\
\cline { 2 - 3 } Parameters & Control & Experimental \\
\hline Erythrocytes (RBC) $\left({ }^{\times} 10^{6} / \mathrm{ml}\right)$ & $1.64 \pm 0.045$ & $1.73 \pm 0.041$ \\
Hemoglobin, $\mathrm{g} / 100 \mathrm{ml}$ & $18.31 \pm 3.15$ & $21.14 \pm 2.20^{*}$ \\
Hematocrits (Packed cell volume), $\%$ & $30.12 \pm 1.23$ & $33.10 \pm 1.04$ \\
Concentration of glucose, mol/l & $7.62 \pm 1.985$ & $7.02 \pm 1.21$ \\
Total protein, g/l & $20.10 \pm 1.87$ & $29.20 \pm 1.32^{*}$ \\
\hline
\end{tabular}

${ }^{*}$ Correlationis Significant at the 0.05 level $(\mathrm{P}<0.05)$

Table 2. Physiological state of carp blood on the background of the influence of the feed factor, $M \pm m, n=20$

\begin{tabular}{|c|c|c|c|c|c|c|c|c|}
\hline \multirow[b]{2}{*}{ Groups } & \multicolumn{4}{|c|}{ Neutrophils } & \multicolumn{4}{|c|}{ Agranulocytes } \\
\hline & Myelocytes & Metamyelocytes & $\begin{array}{l}\text { Rod- } \\
\text { like }\end{array}$ & $\begin{array}{c}\text { Segment- } \\
\text { nucleus }\end{array}$ & Monocytes & Lymphocytes & $\begin{array}{c}\text { Eosinophils, } \\
\text { psevdoeosinophils }\end{array}$ & $\begin{array}{c}\text { Basophils, } \\
\text { psevdobasophils }\end{array}$ \\
\hline Control & $2.6 \pm 0.9$ & $2.9 \pm 0.6$ & $1.5 \pm 0.8$ & $4.1 \pm 0.4$ & $4.6 \pm 1.1$ & $76.8 \pm 1.9$ & $4.9 \pm 0.8$ & $2.5 \pm 0.7$ \\
\hline Experimental & $1.5 \pm 0.2$ & $1.6 \pm 0.4^{*}$ & $1.1 \pm 0.3$ & $2.0 \pm 0.2^{*}$ & $1.8 \pm 0.5^{* *}$ & $87.5 \pm 1.4^{*}$ & $2.8 \pm 0,3^{*}$ & $1.6 \pm 0.6$ \\
\hline
\end{tabular}

${ }^{*}$ Correlationis Significant at the 0.05 level $(\mathrm{P}<0.05)$

**Correlationis Significant at the 0.01 level $(P<0.01)$

support the realization of the biological resource of fish against the background of metabolic processes activation, the increasing daily-average growth etc. In such a case, the each of the methods is not complex and does not involve the use of growing conditions together with the cultivation of natural feed, which is being introduced during feeding. However, in this scientific work, the effectiveness of introduction of the module system with use of the advanced biotechnologies in modern dimension is considered. While in the works by O. Zolotaryov \& Shniukova (2008) biotechnology is defined as a series of technologies that involve the use of biological processes of living organisms in industry, agriculture and other fields. Taking into account that biotechnologies with the use of photo-autotrophs, in particular microalgae, have been developing recently, thus, the topic remains relevant (Boehmer et al., 2005; Honcharova \& Tushnytska, 2018; Zheltov, 2003). The experience of using phytoplankton in the fish breeding is reflected in the scientific work by Merzlova (2014). The author notes the positive effect of chlorella, scenedesmus and spirulina, as they are natural food for many species of fish, and after entering the organism, have a corrective effect on metabolic processes. As an alternative way to increase the protein nutrition of hydrobionts, in particular breeding young- of-the-year of scaly carp suggest the use of compounds with a high content (up to 50\%) of readily available protein and effect of replacing fishmeal with blends of alternative proteins on growth performance of rainbow Oncorhynchus mykiss, and early or late stage juvenile Atlantic salmon (Hrytsynyak et al., 2013; Burr et al., 2012). There are positive results by Goda et al. (2007), which studied effect of totally or partially replacing fish meal by alternative protein sources on growth of African catfish Clarias gariepinus. The available sources of scientific and practical results contain information on the substantiation of positive effect of spirulina, which is due to its structure of the cell wall, formed by the mucopolysaccharides. This supports the digestion of spirulina with the participation of human enzymic complexes in comparison, for example, with unicellular algae (Chlorella), which contains cellulose in the cell wall. In such a manner, it is possible to note to a greater extent a number of advantages, rather than disadvantages of using phytoplankton for improving the metabolic functions of fish (Honcharova et al., 2019). 
The results, obtained in this work on the study of the influence of the feed factor on physiological and biochemical parameters, demonstrated the improvement of oxygen capacity of the carp blood due to increased erythropoiesis and hemoglobin synthesis. The set parameters correlated with the development rate of carp in ontogenesis, which supported the increase of daily average growth, increase of survival rate and better feed coefficient.

\section{Conclusions}

The use of the module system for ongrowing of young carp (Cyprinus carpio L.) in order to stock the aquatories with a viable stock provides activation of physiological and biochemical status of the fish organism. The cultivation of natural feed in the bioreactor involves special processing of microalgae and their introduction into the technological plan against the background of th use of the advanced biotechnologies for monitoring physiological and biochemical processes and the operation of the module unit. The extra feeding of carp in the optimal amount according to the proposed method in the composition of the general ration of Chlorella vulgaris, Spirulina Platensis and Artemia salina supported better growth rates, the difference in the average body weight of the carp fry of the experimental group and the control group was $8,9 \%$, the difference between young-of-the-year fish at the end of the growing season in the control and experimental groups was $12.1 \%$. The highest survival rate of young-of-theyear and two-year fish were registered at the values of $3.4 \%$ and $2.9 \%$ relatively to the control values. It was found that the electromagnetic field, in which the carp was fixated, reflected the state of physiological and biochemical processes of fish organism in terms of radiation intensity. The study of the morphological and functional state of carp blood against the background of the influence of the feed factor reflected the adaptive capacity and functionality of homeostasis of the organism. The number of erythrocytes and hemoglobin content exceeded the values in the control group by 5.5 and $15.5 \%$, respectively. The concentration of glucose in the blood of carp of the control group was less than the values in the experimental group by $7.8 \%$. This may be caused by the activation of metabolic processes and the rapid split of simple sugar compounds in the blood of the experimental carp.

The best qualitative characteristics of the muscular part of the carp, which was on grown in the module system, using natural processed feed in the bioreactor, were obtained. It is worth paying attention to the fact that, in Ukraine, the cultivation of microalgae at the industrial level is still limited due to the imperfection of technological approaches, reduced effectiveness of algae production because of the climatic conditions. The development of optimal technological approaches will provide an opportunity to adapt this technology to the conditions of the South of Ukraine.

\section{Ethical Statement}

Fish were kept in agreement with the European regulations of animal welfare (ETS N8 123, 01/01/91). The research was guided by the principles of bioethics. Our fish facilities are approved for animal experimentation by the Ministry of Education, Science of Youth and Sports of Ukraine (The order of implementation by scientific organizations, enterprises of experiments on animals. Normative document Order N 249, 03/01/2012). The experimental protocol was approved by the Ethics Committee of the Kherson State Agrarian and Economic University.

\section{Funding Information}

Work supported by Ministry of Education and Science of Ukraine (MESU) state budgetary theme ID:0118U003145; ID:62145 2019-10-22 04:24:38 and economic agreements by the Institute of Fisheries of the National Academy of Agrarian Sciences ID: 01.0703.01.07.04.

\section{Author Contribution}

$\mathrm{OH}$ : Project Administration, Resources, Writing original draft and editing; Conceptualization; PK: Formal Analysis, Investigation, Methodology, Funding Acquisition; YK: Visualization and Writing - review and editing.

\section{Conflict of Interest}

The authors declare that they have no known competing financial or non-financial, professional, or personal conflicts that could have appeared to influence the work reported in this paper.

\section{Acknowledgements}

Yuri Kovalyov, director of "Kherson Production and Experimental Plant for Breeding of the Ordinary Fish" State Institution, for providing a practical basis for the research.

\section{References}

Adams, C.A. (1999). Nutricines Food: Components in Health and Nutrition. Nottingham UK, Nottingham University Press, 128.

Alofa, C.S., Oke V., \& Abou, Y. (2016). Effect of replacement of fish meal with broiler chicken viscera on growth, feed utilization and production of African catfish Clarias gariepinus (Burchell, 1822). International Journal of Fisheries and Aquatic Studies, 4(6), 182-186

Alyokyn, O.A. (1970). Osnovy hydrokhymyy. Lenynhrad: Hydrometeoyzdat, 440. (in Russian).

Boehmer, S., Gold, M., Hauser, S., Thomas, B., \& Yourg, A. (2005). Organic Agriculture: Alternative Farming Systems Information Center, NAL, U.S.D.A 
Burr, G.S., Wolters, W.R., Barrows, F.T., \& Hardy, R.W. (2012). Replacing fishmeal with blends of alternative proteins on growth performance of rainbow trout (Oncorhynchus mykiss), and early or late stage juvenile Atlantic salmon (Salmo salar) Aquaculture 334-337, 110-116. https://doi.org/10.1016/j.aquaculture.2011.12.044

Camacho-Rodriguez, J. (2018). Microalgae as a potential ingredient for partial fish meal replacement in aquafeeds: nutrient stability under different storage conditions / J. Applied Phycol. https://doi.org/10.1007/s10811-017-1281-5

Goda, A.M., El-Haroun, E.R., \& Kabir, C.M.A. (2007). Effect of totally or partially replacing fish meal by alternative protein sources on growth of African catfish Clarias gariepinus (Burchell, 1822) reared in concrete tanks. Aquaculture Research. 38, 279-287

Honcharova O.V., \& Tushnytska N.I. (2018). Fiziolohichne obgruntuvannia vykorystannia netradytsiinoho metodu obrobky syrovyny $\mathrm{v}$ akvakulturi // Rybohospodarska nauka Ukrainy. [Fisheries science of Ukraine], № 1, 5464. https://doi.org/10.15407/fsu2018.01.054. (In Ukrainian).

Honcharova O.V., Paranjak, R.P., Rudenko, O.P., \& Lytvyn N.A. (2020). Biological substantiation of improvement of biotechnological map of production of aquaculture products "eco - direction". Ukrainian Journal of Ecology, [Ecology science of Ukraine], 10(1), 261-266. https://doi.org/10.15421/2020_41

Honcharova, O.V. (2019). Physiological and biochemical justification of the method of the treatment of cyanobacteria Spirulina (Arthrospira) platensis when feeding young of the year carp. Abstracts of the International Scientific and Practical Conference, May 2019 Modern Technologies of Propagation and Restocking of Native Fish. Species (pp. 24-26). Mukachevo, Ukraine.

Honcharova, O.V., Paraniak R.P., \& Hutyi, B.V. (2019). Funktsionalnyi stan orhanizmu prisnovodnykh ryb za umov vplyvu abiotychnykh chynnykiv. Naukovyi visnyk Lvivskoho natsionalnoho universytetu veterynarnoi medytsyny ta biotekhnolohii im. S.Z. Gzhytskoho., 21. (90). 82-87 https://doi.org/10.32718/nv/vet-a9014. (In Ukrainian).

Hrynzhevskyi, M.V., \& Pekarskyi, A.V. (2004). Optymizatsiia vyrobnytstva produktsii akvakultury. PolihrafKonsaltynh, 328. (In Ukrainian).

Hrytsyniak, I.I., Chuklin, A.V., \& Buzevych, I.Yu. (2013). Ikhtiolohichni aspekty vyznachennia istotnosti shkody rybnomu hospodarstvu Rybohospodarska nauka Ukrainy. [Fisheries science of Ukraine], Vol. 3, 7-14. http://nbuv.gov.ua/UJRN/rnu_2013_3_3 (In Ukrainian).

Kolty`pin, Yu. A. (1975). Opy`t ispol'zovaniya muki iz lichinok komnatnoj mukhi dlya kormleniya molodi karpa. Byulleten` nauchny`kh rabot.Vol. 4., 60-63. (in Russian).

Korotkov, K., Matravers, P., \& Orlov, D. (2010). Application of electrophoton capture (EPC) analysis based on gas discharge visualization (GDV) technique in medicine: a systematic review. Journal of alternative and complementary medicine, Iss. 16(1), 13-25. (in Russian).
Korzhov, Ye. I., Kutishchev, P.S., \& Honcharova O.V. (2020). Influence of water balance elements change on the salinity regime of the Dnieper-Bug estuary. Abstracts of the III International Scientific and Practical Conference "Innovative development of science and education", May 2020 (pp. 225-231). Athens, Greece.

Matassa, S., Boon, N., Pikaar, I., \& Verstraete, W. (2016). Microbial protein: future sustainable food supply route with low environmental footprint. Microbial biotechnology, 9(5), 568-575

Merzlova, H.V. (2014). Vmist khlorofilu u biomasi spiruliny za dii riznykh doz mikroelementiv u pozhyvnomu seredovyshchi. Biolohiia tvaryn, Vol. 16 (2.), 71-76.

Naukove obhruntuvannia ratsionalnoi hodivli ryb (2002). [Tekst]. Dovidkovo-navch. posib. / I.M. Sherman [ta in.]. Vyshcha osvita, 126 p.(In Ukrainian).

Palamarchuk, R.A., \& Deren, O.V. (2018). Vplyv amarantu Amaranthus (Linnaeus) na yakisni ta produktyvni kharakterystyky dvolitok koropa (Cyprinus carpio (Linnaeus)) za vvedennia yoho do skladu ratsionu. Rybohospodarska nauka Ukrainy. [Fisheries science of Ukraine], 3, 89]102. (In Ukrainian).

Pivovarov. O., Mykolenko. S., \& Honcharova. O. (2018). Development of natural sciences in countries of the European Union taking into account the challenges of XXI. Comprehensive food safety and quality assessment of plasma-chemically activated water usage: Izdevnieciba «Baltija Publishing» [Collective monograph] / The book is compiled by W. Klaczewski, Lublin, Poland. 480.

Sherman, I.M., Heina, K.M., Kutishchev S.V., \& Kutishchev P.S. (2013). Ekolohichni transformatsii richkovykh hidroekosystem ta aktualni problemy rybnoho hospodarstva. Rybohospodarska nauka Ukrainy, [Fisheries science of Ukraine], №4 (26), 5-16. (In Ukrainian).

Sposib biostymuliatsii produktyvnosti koropa. Patent № 64556 (2011). Ukraina. MPK (2011) A 01K 61/00. Deren, O.V., Pirus, R.I., \& Hrytsyniak, I.I. Opublikovano 10.11.2011. Biul. №21(In Ukrainian).

Sposib vyznachennia zhyvykh zarodkiv $v$ period inkubatsii yaiets. Patent № 111577UA (2016). Ukraina. Kobets A. S., Honcharova, O.V., \& Puhach, A.M. Opublikovano 10.11.2011. Biul. № 21(In Ukrainian).

Vainshelboim, A.L., Hayes, M.T., Korotkov, K.G. \& Momoh, K.S. (2005). GDV Technology Applications for Cosmetic Sciences. [Symposium], IEEE 18th Symposium on Computer-Based Medical Systems, Dublin.

Wan, A.H. (2019). Macroalgae as a sustainable aquafeed ingredient. Reviews in Aquaculture, Vol. 11 (3), 458-492. https://doi: 10.1111/raq.12241.

Zheltov, Yu. A. (2008). Ratsyonalnoe kormlenye karpovykh ryb $v$ akvakulture. Kyev, 408. (in Russian).

Zheltov, Yu. O. (2003). Metodychni vkazivky z provedennia doslidiv po hodivli ryb. Rybne hospodarstvo. [Fisheries science of Ukraine], Vol. 62., 23-28. (In Ukrainian).

Zolotarova, O.K. \& Shniukova, Ye.I. (2008). Perspektyvy vykorystannia mikrovodorostei u biotekhnolohii. Kyiv: Alterpres, 234. (In Ukrainian). 